\title{
Karakteristik dan Dinamika Nelayan Rawa Pening ( Kasus Kecamatan Banyubiru )
}

\author{
Eka Wulan Safriani ${ }^{1 *}$, Rani Dwi Jayanti ${ }^{1}$, Merselena ${ }^{1}$, Fadly Nuryawan ${ }^{1}$, Tasya Vima Eka ${ }^{1}$, \\ Gesang Nur Wahyudi ${ }^{1}$, Rusmani Hadi ${ }^{1}$, Ana Zahiratul Mufida ${ }^{1}$, Yunus Aris Wibowo ${ }^{1}$ \\ ${ }^{1}$ Program Studi Pendidikan Geografi, Universitas Muhammadiyah Surakarta, Jl. A. Yani Pablan \\ Kartasura Surakarta 57102, Indonesia) \\ Email :*a610170016@student.ums.ac.id, ranidwijayanti7@gmail.com , \\ lenamerselena@gmail.com,fadlynuryawan16@gmail.com, rasidah-tashavima280815@gmail.com, \\ gesangnurwahyudi0@gmail.com,rh20.rh17@gmail.com, anajatisari@gmail.com, \\ yunusariswibowo@gmail.com
}

Dikirim : Tanggal Bulan Tahun

Diterima: Tanggal bulan Tahun

\begin{abstract}
Abstrak: Penelitian ini mengkaji tentang karakteristik dan dinamika sosial ekonomi masyarakat nelayan di Kecamatan Banyubiru. Penelitian ini bertujuan mengetahui aspek sosial ekonomi masyarakat nelayan yang mencakup pendidikan, lama menjadi nelayan, usia rata-rata, pendapatan, serta dinamika perubahannya. Populasi penelitian berjumlah 191 nelayan dengan sampel yang diambil sebanyak 115 nelayan menggunakan teknik proporsional random sampling. Hasil penelitian menyimpulkan : 1) ratarata tingkat pendidikan nelayan tergolong rendah dengan presentase tertinggi sebesar $57,14 \%$ pada kelompok nelayan Minarejeki dan Rowoganjar, 2) Usia rata-rata nelayan memasuki usia masa lansia yaitu dengan umur 51-66 tahun sebesar 42,25\%, serta hampir semasa usianya menjadi nelayan, 3) tingkat pendapatan rata-rata nelayan tergolong dalam kelas rendah dengan presentase tertinggi sebesar $94,44 \%, 4)$ terjadi dinamika pada kelompok nelayan sebagai upaya peningkatan taraf hidup dengan presentase sebesar 1,6\% kelompok nelayan yang beralih ke nelayan keramba.
\end{abstract}

Kata kunci: dinamika, ekonomi, nelayan, sosial

\begin{abstract}
Berisi terjemahan abstrak Bahasa Indonesia ke dalam Bahasa Inggris dengan aturan penulisan yang sama. This study examines the characteristics and socio-economic dynamics of fishing communities in Banyubiru District. This study aims to determine the socio-economic aspects of fishing communities which include education, length of time being a fisherman, average age, income, and the dynamics of change. The research population was 191 fishermen with 115 fishermen using proportional random sampling technique. The results of the study concluded: 1) the average level of education of fishermen is low with the highest percentage of $57.14 \%$ in the fishermen group Minarejeki and Rowoganjar, 2) The average age of fishermen entering the age of the elderly is 51-66 years of age 42, $25 \%$, and almost during his age as a fisherman, 3) the average income level of fishermen is classified as low with the highest percentage of $94.44 \%, 4$ ) they are dynamics in the fishermen group as an effort to improve living standards with a percentage of $1.6 \%$ groups of fishermen who switch to cage fishermen.
\end{abstract}

Keywords: dynamics, economy, fishermen, social

\section{Pendahuluan}

Indonesia dikenal sebagai negara kepulauan terluas di dunia dengan garis pantai $81.000 \mathrm{~km}$ dan memiliki 17.508 buah pulau (Ulfa, 2018). Potensi keanekaragaman hayati yang dimiliki Indonesia sangat berlimpah. Bidang perikanan merupakan salah satu potensi keanekaragaman hayati yang dimiliki Indonesia. Tidak kurang dari 2.000 spesies ikan terdapat diperairan Indonesia, baik perairan laut maupun perairan tawar seperti danau, rawa, sungai, dan lain-lain. Perikanan merupakan salah satu aktifitas ekonomi bagi masyarakat Indonesia yang sangat 
kompleks. Perikanan dianggap mampu memberikan nilai ekonomi serta kesejahteraan bagi masyarakat, utamanya untuk para nelayan. Jumlah hasil penangkapan ikan yang diperoleh nelayan merupakan faktor utama jumlah pendapatan yang akan diperoleh guna memenuhi kebutuhan hidupnya.

Nelayan merupakan masyarakat yang kehidupannya bergantung dengan penangkapan ikan maupun budidaya keramba. Nelayan di Indonesia rata-rata sudah turun temurun dari keluarga yang terdahulu seperti nelayan di Danau Rawa Pening. Masyarakat secara umum banyak yang menggunakan alat tangkap tradisional. Hasil penangkapan ikan di rawa pening merupakan faktor utama untuk memenuhi kehidupan sehari-hari. Masyarakat ini setiap hari hasil tangkapan ikannya di jual ke pengepul jadi harga ikannya setiap harinya stabil (Sebenan, 2007). Karakteristik yang menjadi ciriciri sosial masyarakat nelayan adalah etos kerja yang tinggi, memanfaatkan kemampuan terhadap keahlian yang dimiliki, terbuka dan memiliki solidaritas yang tinggi (Adinda, 2015).

Tingkat pendidikan menjadi salah satu karakteristikkeadaan yang terjadi pada kehidupan nelayan. Hal tersebut dapat diukur dengan ketersediaan sarana prasarana, tingkat pendidikan nelayan, dan kondisi kesehatan nelayan (Herdian, 2003).

Dinamika kehidupan nelayan bergantung pada perubahan iklim. Perubahan iklim membawa pengaruh pada kehidupan sosial ekonomi nelayan. Adanya perubahan iklim mengakibatkan nelayan tidak dapat menentukan musim-musim yang akan terjadi. Perubahan iklim berdampak pada kondisi cuaca yang ekstrim sehingga nelayan tidak berani untuk melaut. Tidak hanya berdampak pada kondisi cuaca, perubahan iklim juga membuat sumber daya perikanan yang semakin berkurang oleh karena itu nelayan memilih untuk mencari ikan dengan jarak yang lebih jauh. Hal ini juga beresiko mengubah stabilitas ekonomi, sosial ekonomi masyarakat. Modal ekonomi yang dimiliki masyarakat nelayan adalah pendapatan yang diperoleh dari pekerjaan mencari ikan di laut dan alat-alat yang digunakan untuk melaut. Dapat diketahui bahwa pada masyarakat nelayan modal ekonomi yang diperoleh pada mulanya berawal dari modal budaya sebagai jembatan untuk memperoleh modal-modal lain untuk mencapai tujuan. Hubungan yang terjalin dalam masyarakat nelayan merupakan interaksi yang terjadi berdasarkan sosial dan budaya masyarakat (Mariam, 2018).

Perairan Rawapening merupakan sumberdaya perairan dengan luasan $2.380 \mathrm{Ha}$ yang terletak pada ketinggian 463,30 mdpl. Perairan Rawapening ini memiliki potensi sumberdaya perikanan yang dapat dimanfaatkan oleh nelayan yang tinggal di sekitar Rawapening (Dinas Peternakan dan Perikanan Kabupaten Semarang, 2010). Jumlah nelayan yang menggantungkan hidupnya pada sumberdaya Danau Rawapening 1.589 orang (Mandika, 2013).

Kecamatan Banyubiru merupakan salah satu kecamatan yang berada di Kabupaten Semarang, sebagian masyarakat disana yang tinggal disekitar Danau Rawa Pening bekerja sebagai nelayan. Pendapatan yang diperoleh nelayan tidak menetap dan terkadang hanya mampu untuk mencukupi kebutuhan sehari-hari, sementara biaya pendidikan yang tinggi menjadi salah satu faktor penghambat bagi nelayan dengan status sebagai masyarakat miskin. Akibat ketidakpastian pendapatan yang diperoleh nelayan, terjadilah dinamika pada kelompok nelayan di Kecamatan Banyubiru. Dinamika ini terjadi pada kelompok nelayan tangkap beralih menjadi nelayan enceng gondok maupun nelayan keramba yang lebih menjanjikan hasilnya. Peralihan tersebut menjadi hal yang sangat unik untuk dikaji. Latar belakang perubahan menjadi nelayan enceng gondok karena secara kuantitas, sumberdaya eceng gondok di Danau Rawa Pening sangat melimpah dan bisa menjanjikan penghasilan yang lebih pasti dibandingkan nelayan tangkap. Sedikitnya jumlah nelayan keramba dikarenakan besarnya modal yang dibutuhkan untuk membuat keramba dan perawatan keramba sehingga tidak semua nelayan mampu membuat keramba. 
Melihat kondisi karakteristik serta dinamika masyarakat nelayan yang unik di Kecamatan Banyubiru khususnya masyarakat yang tinggal disekitar Danau Rawapening, maka perlu dilakukan penelitian dengan judul penelitian "Karakteristik dan Dinamika Nelayan Rawa Pening (Kasus Kecamatan Banyubiru)". Dari penelitian tersebut digunakan untuk mengetahui tingkat karakteristik masyarakat nelayan yang ada di Kecamatan Banyubiru serta proses dinamika sosial ekonomi yang dihadapi oleh masyarakat nelayan tersebut. Selanjutnya dapat juga dijadikan sebagai dasar untuk pengembangan dan perencanaan bagi masyarakat untuk meningkatkan taraf kesejahteraan masyarakat nelayan di Kecamatan Banyubiru.

\section{Metode Penelitian}

Metode penelitian ini berupa analisis deskriptif kuantitatif, dengan penyajian data melalui tabel, grafik, diagram, dan presentase. Penelitian ini dilakukan pada 3 desa nelayan di Kecamatan Banyubiru, karena desa tersebut memiliki jumlah nelayan yang lebih dominan dibanding jumlah nelayan di desa lain.

Tabel 1. Data Sampel per-kelompok nelayan

\begin{tabular}{|l|l|l|l|}
\hline No & \multicolumn{1}{|c|}{ Desa } & \multicolumn{1}{|c|}{ Nama Kelompok Nelayan } & \multicolumn{1}{|c|}{ Sampel } \\
\hline 1 & Rowoboni & Banjangaran & 17 \\
\hline 2 & Rowoboni & Minarejeki & 15 \\
\hline 3 & Rowoboni & Rowoganjar & 20 \\
\hline 4 & Banyubiru & Banyubiru & 14 \\
\hline 5 & Kebondowo & KUB Mudimulyo & 33 \\
\hline 6 & Kebondowo & KUB Margomulyo & 16 \\
\hline \multicolumn{2}{|l|}{ Jumlah } & $\mathbf{1 1 5}$ \\
\hline
\end{tabular}

(Sumber: Penelitian, 2019)

Jumlah populasi penelitian merupakan kelompok nelayan yang berada di sekitar danau Rawa Pening se-Kecamatan Banyubiru dengan jumlah 191 nelayan dengan sampel yang diambil sebanyak 125 nelayan. Pengambilan sampel dengan teknik proporsional random sampling dengan menggunakan metode slovin.

\section{Pengumpulan data}

Teknik pengumpulan data menggunakan kuesioner berupa angket dengan metode tertutup, dimana kemungkinan pilihan jawaban sudah ditentukan terlebih dahulu dan responden tidak diberikan alternatif jawaban lain. Teknik pengumpulan data digunakan untuk mengetahui perbedaan karakteristik serta dinamika yang ada pada setiap kelompok nelayan di Kecamatan Banyubiru. Data karakteristik dan dinamika nelayan berupa pendidikan, lama menjadi nelayan, usia nelayan, tingkat pendapatan, serta dinamika perubahan matapencahariannya. Data tingkat pendapatan diperoleh dari hasil tangkap yang didapat serta harga per kilogram ikan yang dihitung selama satu bulan.

\section{Analisis data}

Data yang diperoleh di lapangan (primer) maupun data sekunder disusun dan dikelompokkan kemudian dianalisis. Teknik analisis yang digunakan dalam penelitian ini adalah dengan menggunakan analisis deskriptif kualitatif. Penelitian deskriptif kuantitatif bertujuan untuk menjelaskan fenomena yang ada. Analisis yang dilakukan diantaranya:

1. Analisis Karakteristik Nelayan

Analisis yang digunakan yaitu deskriptif kuantitatif berdasarkan pada indikator sosialekonomi dari masing-masing kelompok nelayan yang ada di Kecamatan Banyubiru. 
Analisis ini digunakan guna untuk mengetahui perbedaan tingkat pendidikan, tingkat usia, serta lama mereka bermatapencaharian sebagai nelayan dimasing-masing kelompok serta faktor penyebabnya.

2. Analisis Tingkat Pendapatan Nelayan

Analisis yang digunakan menggunakan pengolahan statistik dari data yang diambil di lapangan melalui kuesioner. Hasil yang didapat berupa jenis ikan yang didapat nelayan, perubahan harga ikan oleh tengkulak, serta banyaknya ikan yang didapat oleh nelayan setiap kali menangkap ikan. Data tersebut dianalis secara deskriptif kemudian diolah melalui exel untuk mendapatkan pendapatan nelayan secara keseluruhan.

3. Analisis Dinamika Nelayan

Metode analisis yang digunakan berupa diskripsi dan pengolahan data yang diambil melalui kuesioner serta wawancara terbuka kepada nelayan yang ada di Kecamatan Banyubiru.

\section{Hasil Penelitian dan Pembahasan}

1. Tingkat Pendidikan Nelayan di Kecamatan Banyubiru

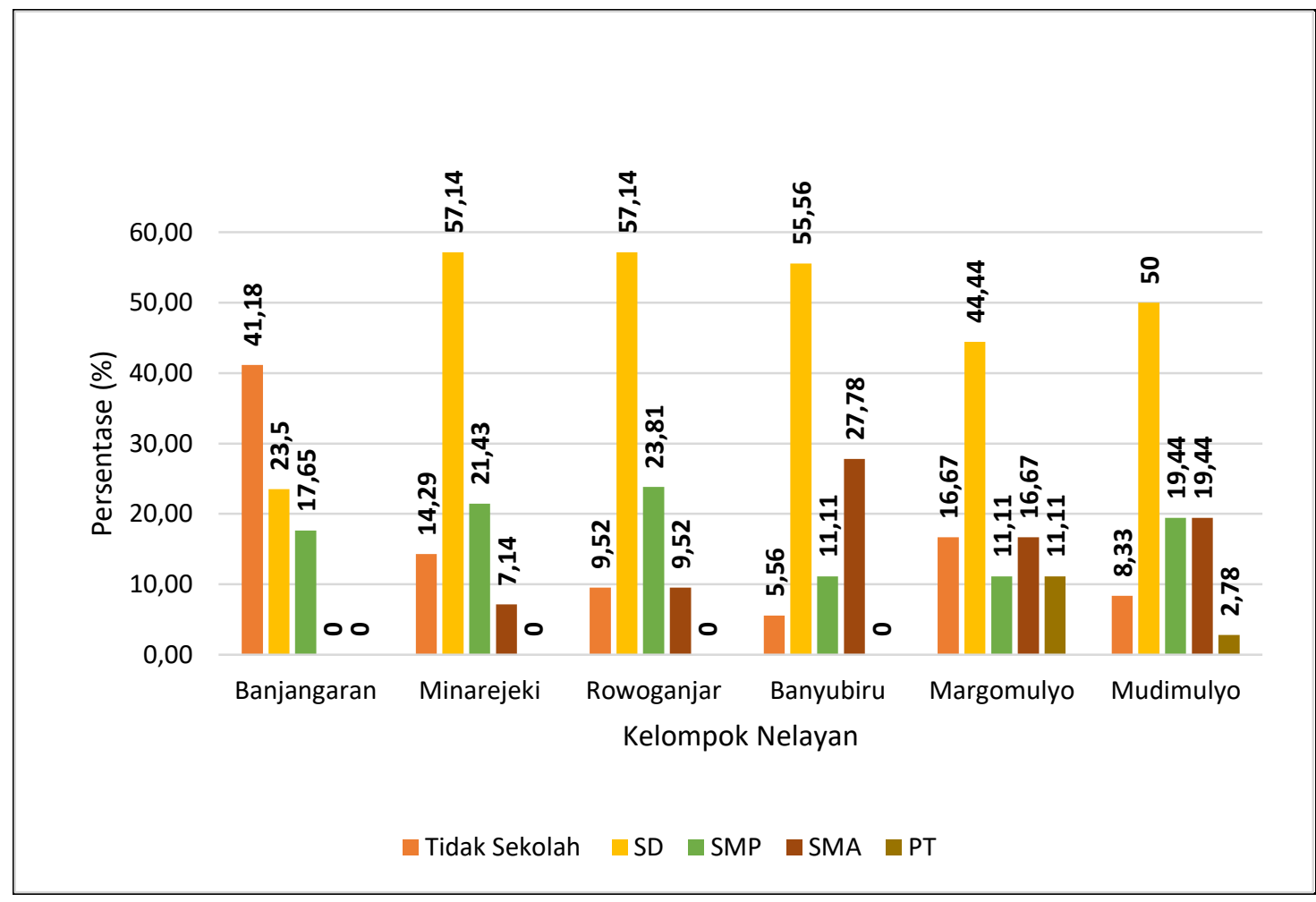

Gambar 1. Tingkat pendidikan nelayan di Kecamatan Banyubiru (sumber: Penelitian 2019)

Hasil analisis data menunjukkan bahwa rata-rata tingkat pendidikan dari masing-masing kelompok nelayan tergolong rendah yakni tingkat SD dengan presentase tertinggi sebesar $57,14 \%$ pada kelompok nelayan Minarejeki yaitu sebanyak 8 orang dan Rowoganjar yaitu sebanyak 12 orang (Gambar 1). Hal ini menunjukkan bahwa kelompok nelayan Banjangaran memiliki tingkat pendidikan paling rendah dibanding kelompok nelayan lainnya dengan presentase sebesar 41,18 \% yaitu sebanyak 7 orang tidak tamat SD sedangkan kelompok nelayan Margomulyo memiliki tingkat pendidikan paling tinggi dibanding kelompok nelayan lainnya, dengan presentase sebesar $11,11 \%$ yaitu sebanyak 2 orang lulusan Perguruan Tinggi (D3 hingga S1). Rendahnya tingkat pendidikan pada kelompok nelayan sebagian besar 
dipengaruhi oleh kurang mampunya keadaan nelayan pada saat itu. Meskipun pendidikan para nelayan di Kecamatan Banyubiru rata-rata rendah, mereka tetap berusaha menyekolahkan anak-anaknya sampai jenjang pendidikan yang lebih layak. Adapun beberapa nelayan yang memiliki pendidikan tingkat menegah ke atas mereka merupakan sebagian masyarakat migrasi atau bukan penduduk asli di Kecamatan Banyubiru (Gambar 2).

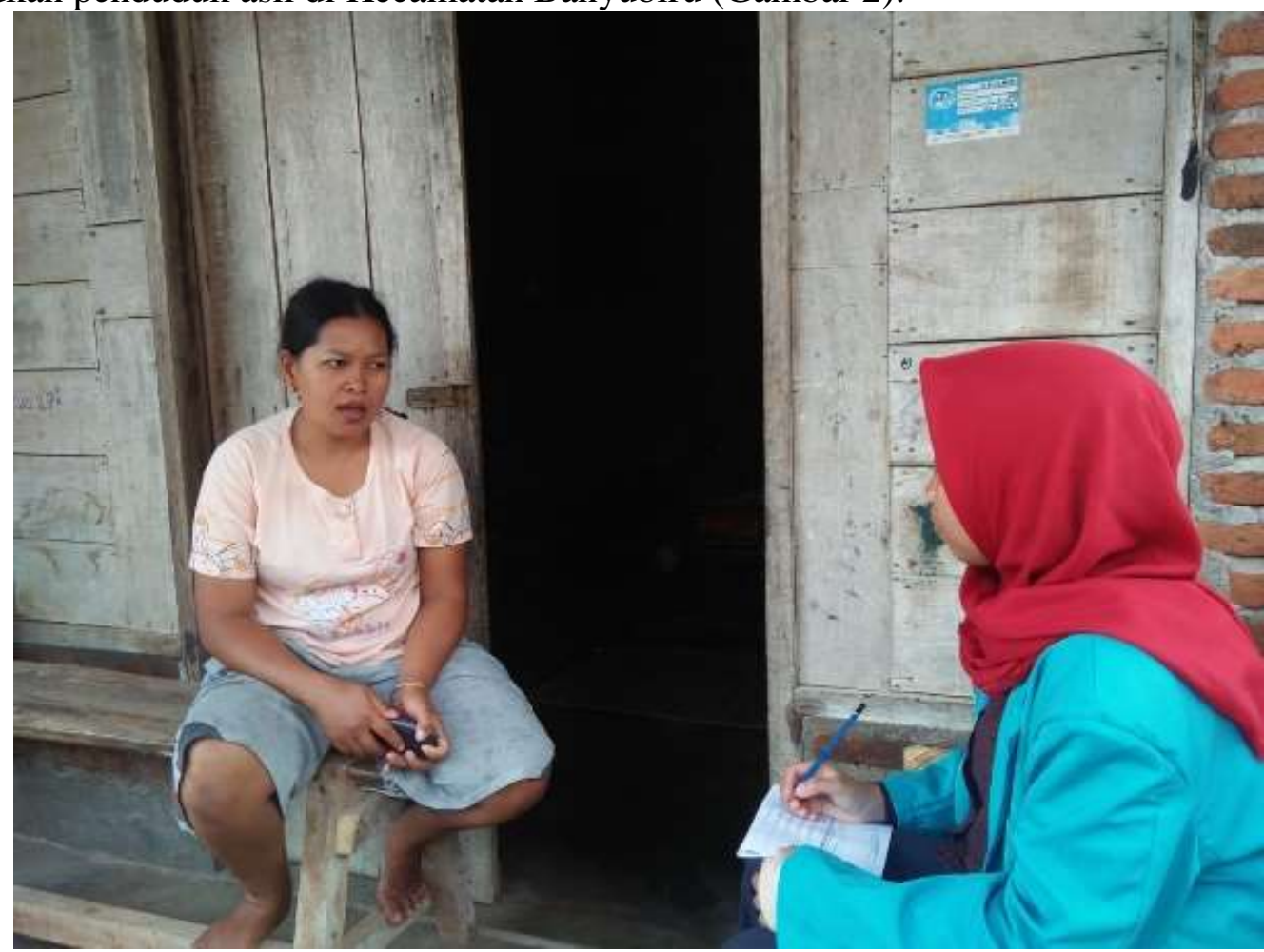

Gambar 2. Nelayan dengan pendidikan tamat SD (Sumber: Penelitian, 2019)

2. Usia Nelayan di Kecamatan Banyubiru 


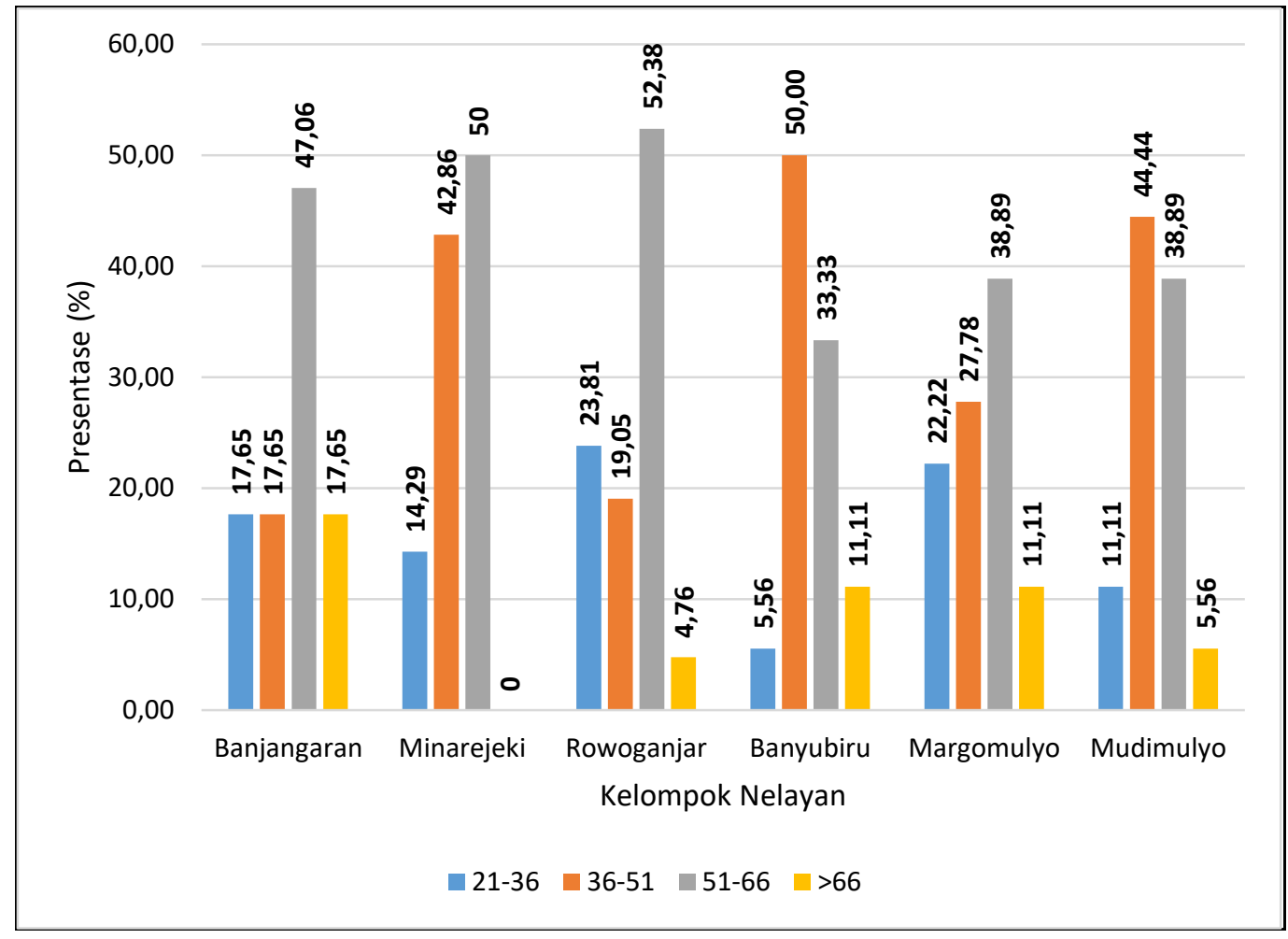

Gambar 3. Tingkat Usia Nelayan di Kecamatan Banyubiru

Hasil analisis data menunjukkan tingkat usia nelayan yang memiliki usia $>66$ tahun paling tinggi terdapat pada kelompok nelayan Banjangaran yaitu sebesar 17,65 \% sebanyak 3 orang, sedangkan kelompok nelayan yang memiliki usia termuda paling tinggi terdapat pada kelompok nelayan Rowoganjar, yaitu sebesar 23,81 \% sebanyak 5 orang (Gambar 3). Kelompok nelayan yang memiliki distribusi usia seimbang terdapat pada kelompok nelayan Margomulyo dan kelompok nelayan yang memiliki distribusi usia paling tidak seimbang terdapat pada kelompok nelayan Minarejeki.

Dapat disimpulkan bahwa tingginya usia para nelayan tidak mempengaruhi semangat mereka dalam bekerja. Pada nelayan di Kecamatan Banyubiru memiliki etos kerja yang tinggi. Para nelayan mampu memanfaatkan sumberdaya Rawa Pening yang ada secara maksimal meskipun hasil yang didapat belum sesuai yang diharapkan (Gambar 4). 


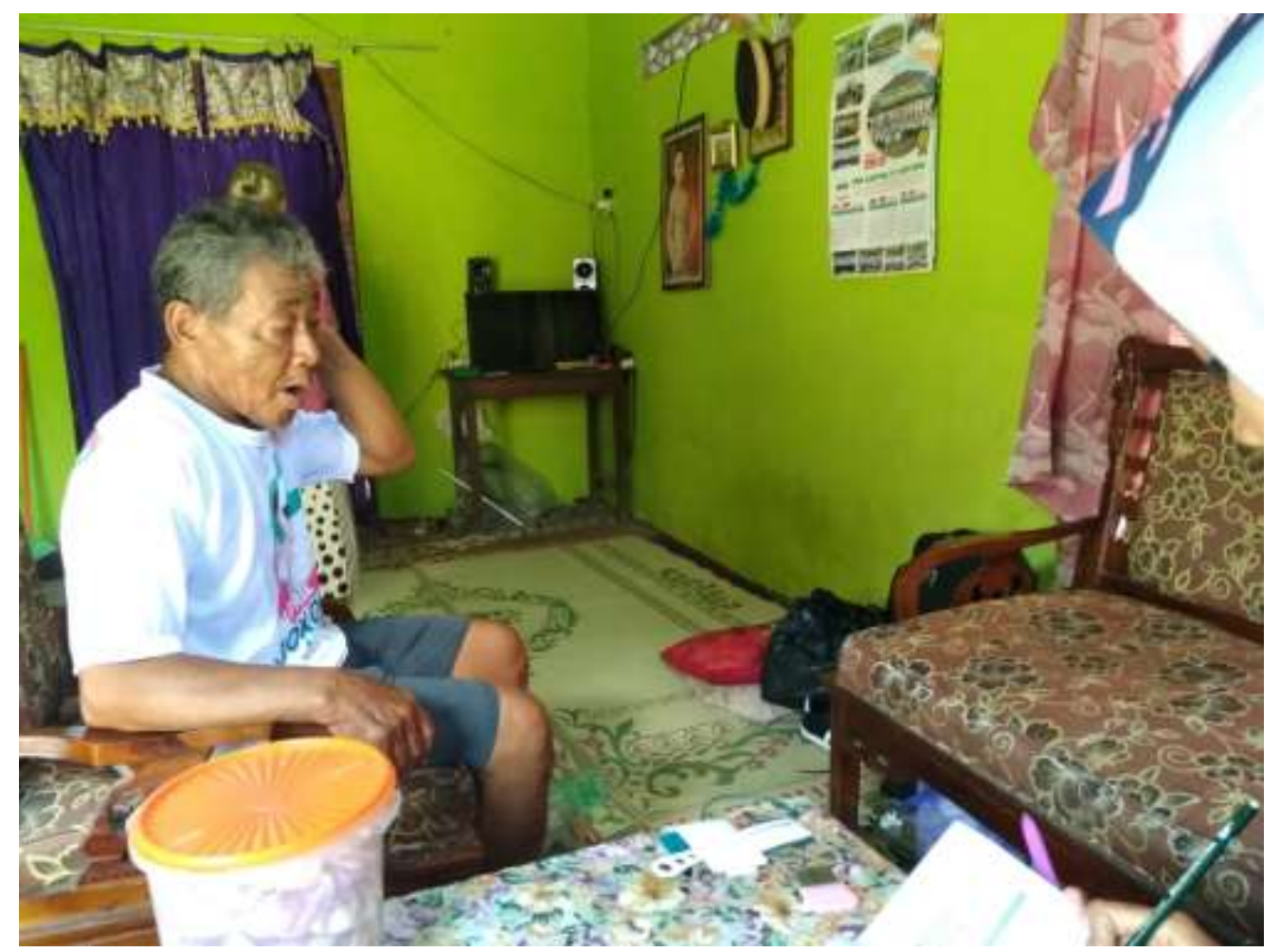

Gambar 4. Nelayan dengan usia >66 tahun (Sumber: Penelitian, 2019)

3. Lama Menjadi Nelayan di Kecamatan Banyubiru

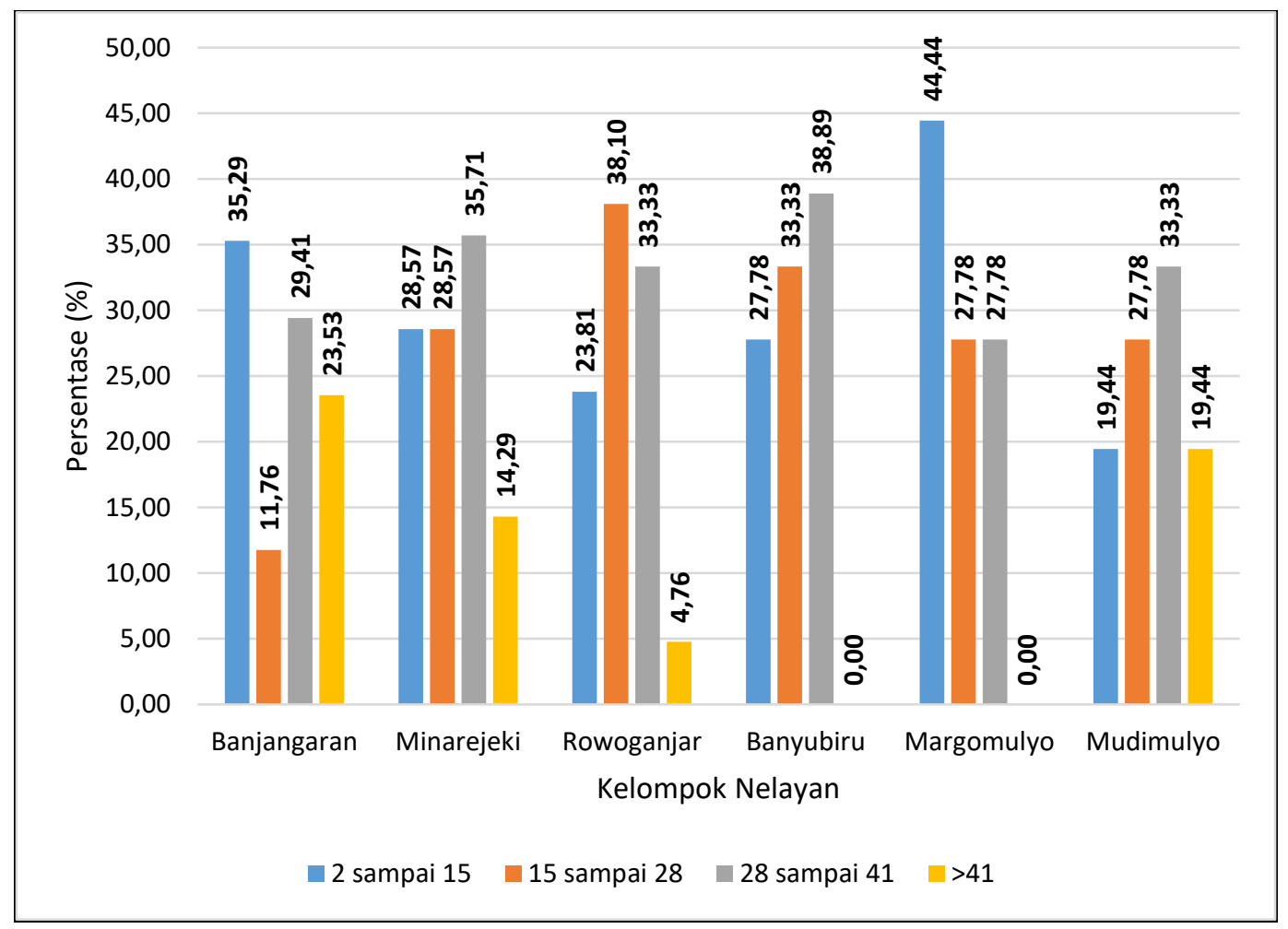

Gambar 5. Lama Menjadi Nelayan di Kecamatan Banyubiru (Sumber: Penelitian, 2019)

Hasil analisis data menunjukkan bahwa rata-rata lama bermatapencaharian sebagai nelayan di Kecamatan Banyubiru adalah selama 28 sampai 41 tahun. Data tertinggi terdapat pada kelompok nelayan Margomulyo dengan presentase sebesar 44,44\% sebanyak 8 orang dengan 
lama menjadi nelayan 2 sampai 15 tahun (Gambar 5). Data terendah terdapat klompok nelayan Banyubiru dan Margomulyo dengan dengan presentase sebesar 0\% dengan lama menjadi nelayan lebih dari 41 tahun.

Lamanya para nelayan di Kecamatan Banyubiru menjadi nelayan disebabkan oleh kondisi keadaan yang menuntut para nelayan menjadi nelayan sejak kecil hingga sekarang. Menurut tutur dari beberapa nelayan bahwa bagi mereka nelayan sudah menjadi nafas mereka. Meskipun memiliki pekerjaan selain menjadi nelayan, mereka tetap menjadikan nelayan sebagai sumber mata pencaharian utama (Gambar 6).

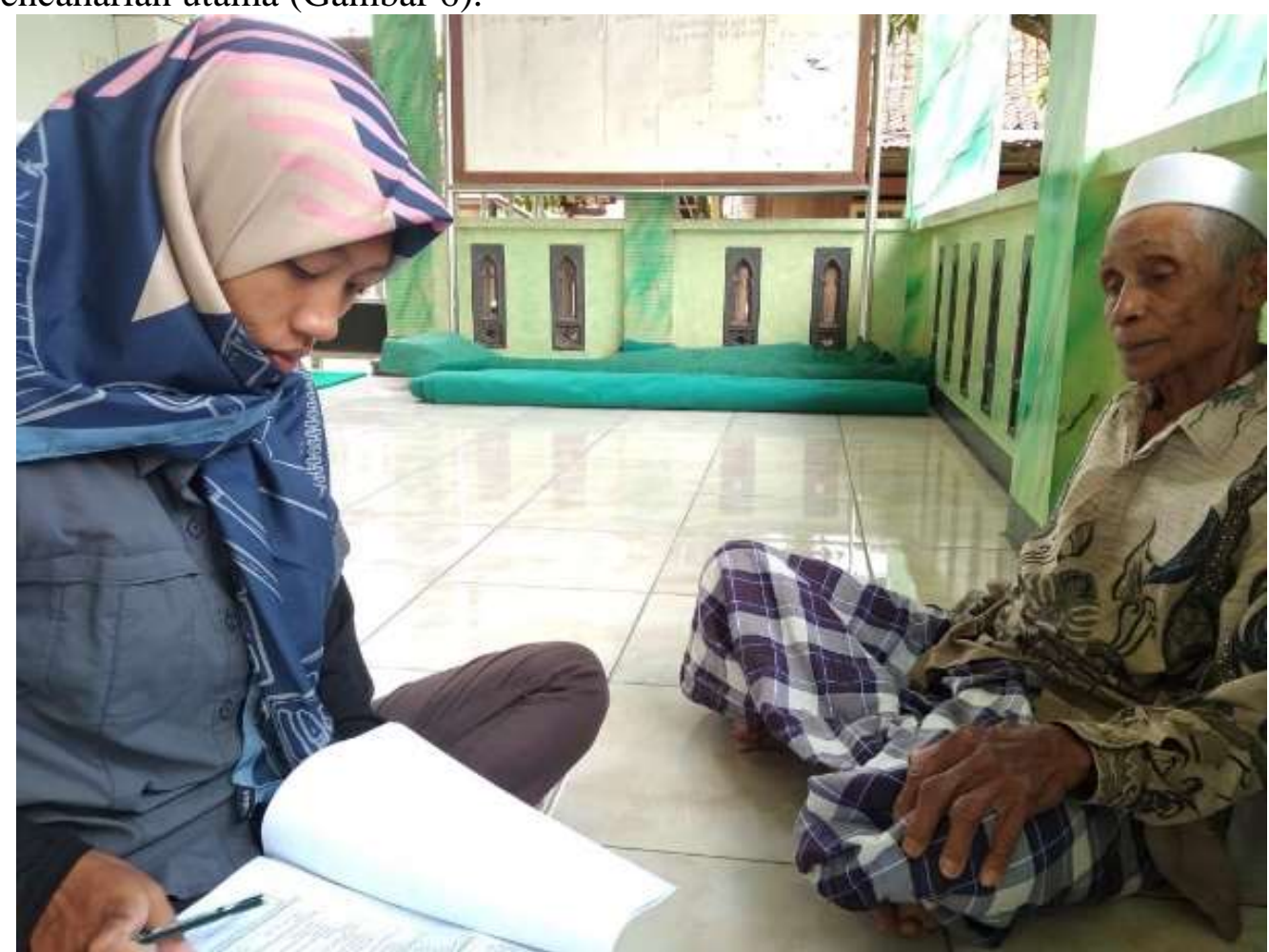

Gambar 6. Nelayan dengan lama menjadi nelayan semasa usia (Sumber: Penelitian 2019) 
4. Tingkat Pendapatan Nelayan di Kecamatan Banyubiru

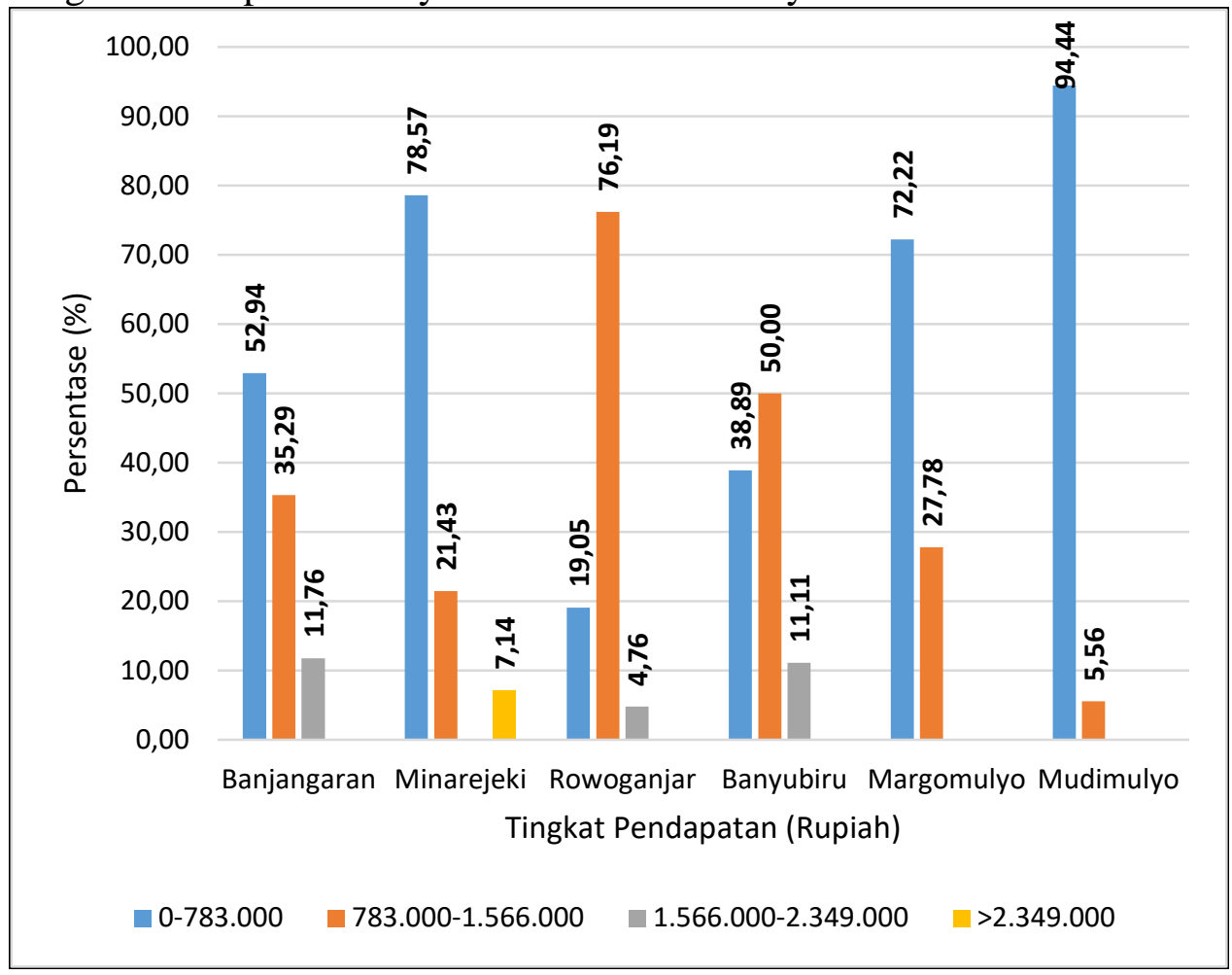

Gambar 7. Tingkat pendapatan nelayan (Sumber: Penelitian, 2019)

Hasil analisis data menunjukkan bahwa rata rata pendapatan nelayan di Kecamatan Banyubiru tergolong rendah. Dapat dilihat bahwa rata-rata pendapatan seluruh nelayan sebesar 0 sampai Rp. 783.000, 00 perbulan. Presentase tertinggi terdapat pada kelompok nelayan Mudimulyo dengan presentase sebesar 94,44\% sebanyak 35 orang. Sedangkan nelayan dengan pendapatan tinggi lebihdari Rp. 2.349.000, 00 sebesar 7,14 \% sebanyak 1 orang terdapat pada kelompok nelayan Minarejeki (Gambar 7). Hal ini menunjukkan bahwa kelompok nelayan yang paling maju yaitu kelompok nelayan Minarejeki.

Dapat diketahui bahwa rendahnya pendapatan nelayan di Kecamatan Banyubiru tentu tidak mencukupi untuk kebutuhan sehari-hari. Ditemukan beberapa nelayan di Kecamatan Banyubiru yang memiliki sampingan sebagai penggarap sawah, menjadi tukang, maupun membuka toko klontong. Rendahnya pendapatan nelayan ini dipengaruhi beberapa faktor, diantaranya kondisi alam yang tidak menentu menjadikan nelayan kesulitan dalam mendapatkan ikan. Selain itu rendahnya harga ikan yang diberikan oleh tengkulak dengan susah payahnya nelayan dalam mendapatkan ikan. Selain itu kondisi perahu yang sudah tidak layak juga menghambat nelayan untuk mencari ikan, karena untuk mengganti perahu yang rusak membutuhkan biaya yang cukup mahal. Pendapatan nelayan juga dipengaruhi oleh tingkat pendidikan nelayan yang rendah menjadikan nelayan sulit mendapatkan pekerjaan yang lebih layak (Gambar 8 dan 9). 


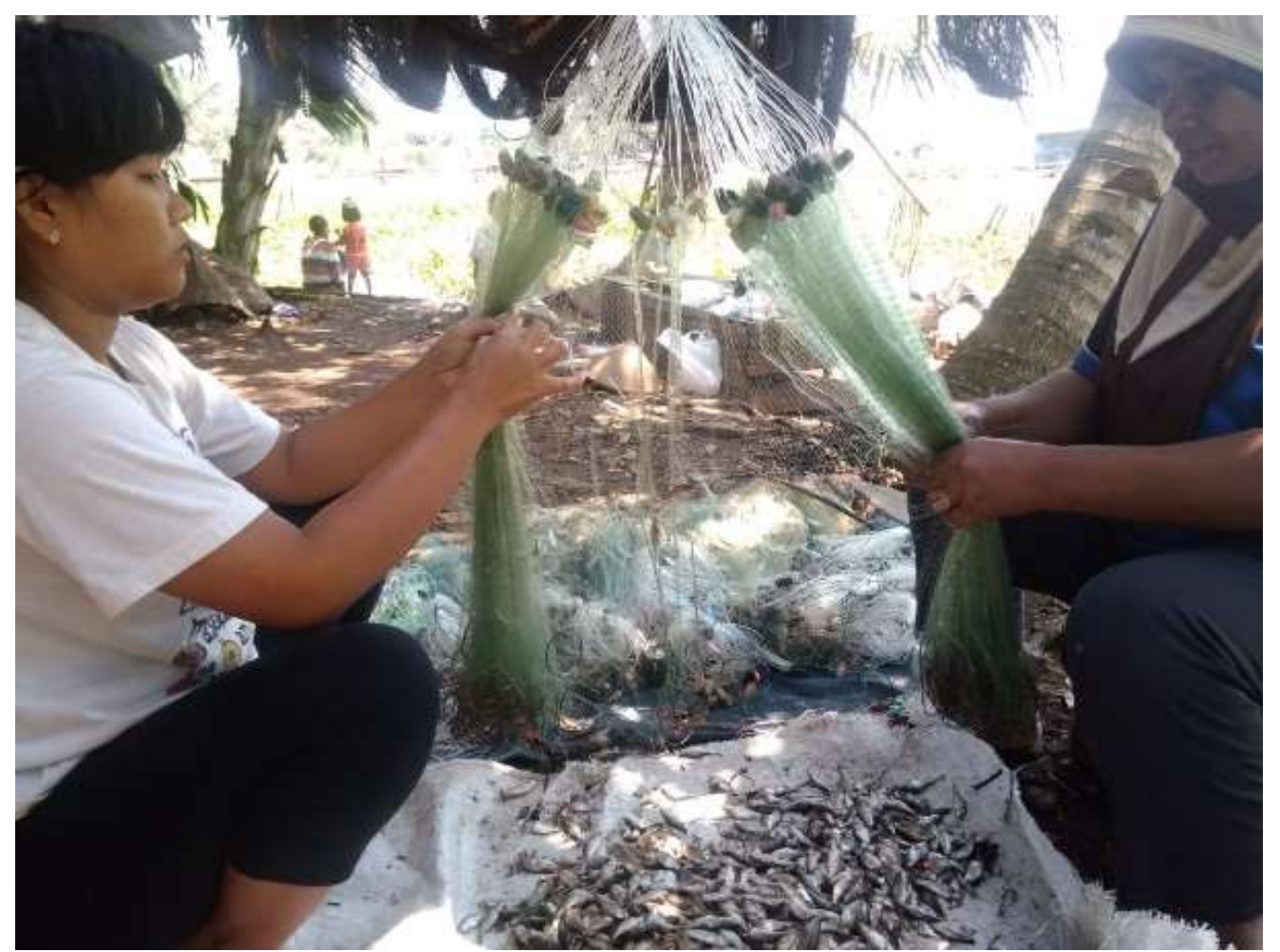

Gambar 8. Hasil tangkapan ikan nelayan tangkap (Sumber: Penelitian, 2019)

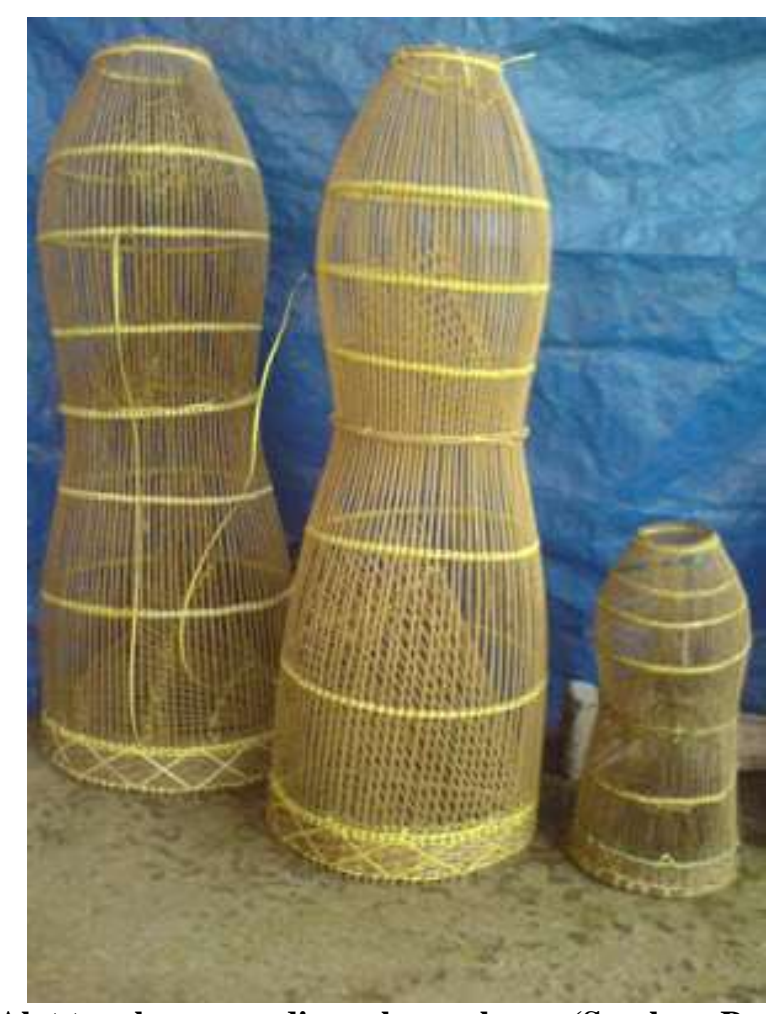

Gambar 9. Alat tangkap yang digunakan nelayan (Sumber: Penelitian, 2019) 
5. Dinamika Nelayan di Kecamatan Banyubiru

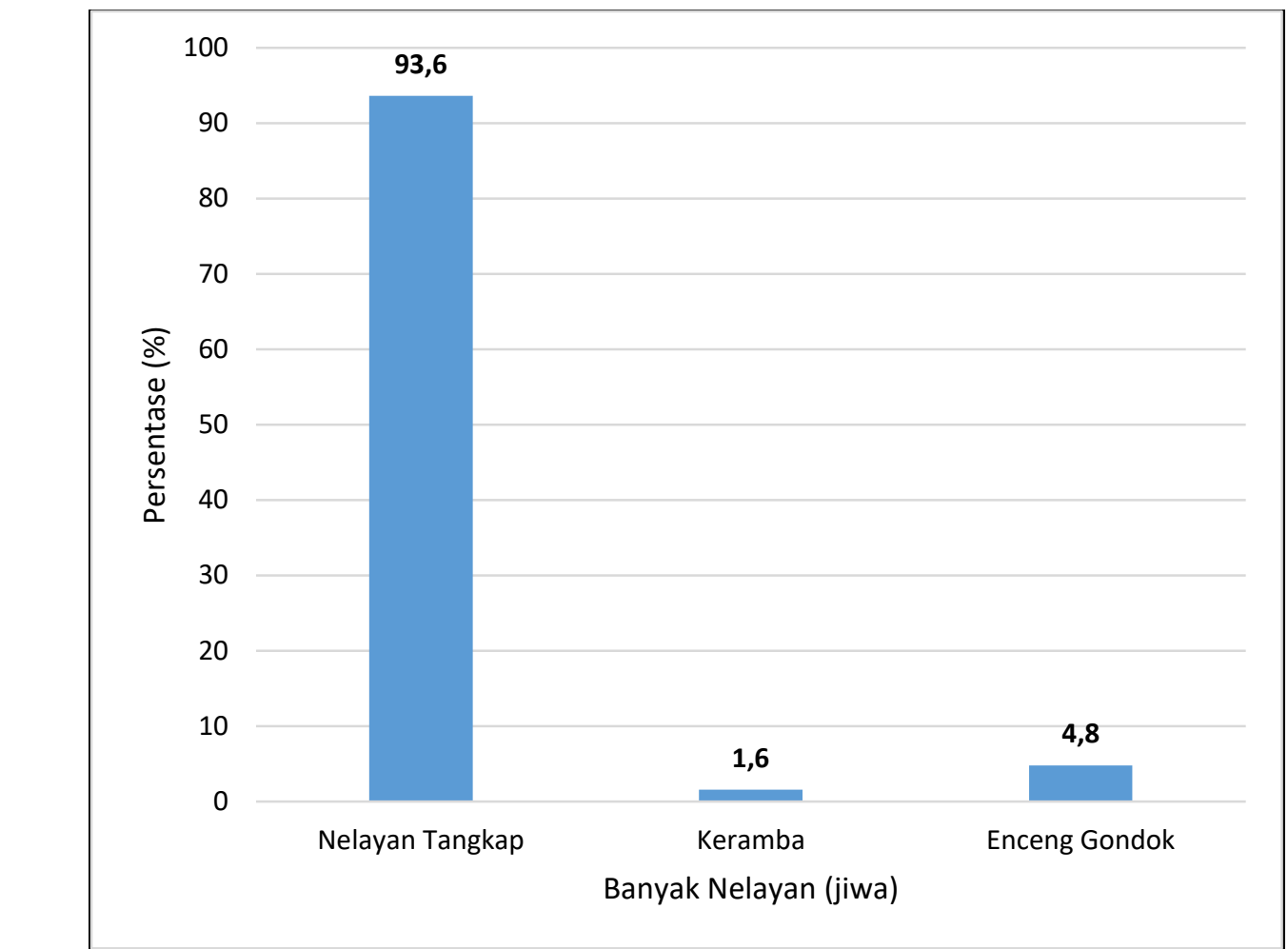

Gambar10. Dinamika perubahan matapencaharian nelayan di Kecamatan Banyubiru (Sumber: Penelitian, 2019)

Hasil observasi menunjukkan bahwa kelompok nelayan di Kecamatan Banyubiru didominasi oleh nelayan tangkap dengan persentase sebesar 93,6 \% sebanyak 117 orang. Hal yang sangat menarik adalah dinamika nelayan, terdapat kelompok nelayan tangkap yang beralih menjadi nelayan keramba sebesar 1,6 \% sebanyak 2 orang, sedangkan yang beralih menjadi nelayan eceng gondok sebesar 4,8 \% sebanyak 6 orang (Gambar 10). Penggunaan istilah nelayan eceng gondok kurang sesuai karena eceng gondok merupakan tanaman yang sebenarnya adalah hama, namun demikian istilah nelayan tetap digunakan karena nelayan tersebut tetap terdaftar sebagai kelompok nelayan serta aktif dalam kegiatan kelompok nelayan.

Dinamika kelompok nelayan di Kecamatan Banyubiru yang sangat menarik untuk dikaji adalah peralihan matapencaharian dari nelayan tangkap ke nelayan keramba maupun enceng gondok. Hal itu dikarenakan hasil perelohan nelayan tangkap yang tidak menentu karena pengaruh kondisi cuaca yang tidak menentu. Sebagian nelayan beralih menjadi nelayan keramba karena menjanjikan penghasilan yang lebih baik, sedangkan latar belakang perubahan menjadi nelayan enceng gondok karena secara kuantitas, sumberdaya eceng gondok di Rawa Pening sangat melimpah dan bisa menjanjikan penghasilan yang lebih pasti dibandingkan nelayan tangkap. Sedikitnya jumlah nelayan keramba dikarenakan besarnya modal yang dibutuhkan untuk membuat dan perawatan keramba sehingga tidak semua nelayan mampu membuat keramba. Dapat disimpulkan bahwa dinamika nelayan tersebut terjadi karena latar belakang ekonomi, yaitu untuk meningkatkan taraf hidup masyarakat nelayan (Gambar 11 dan 12). 

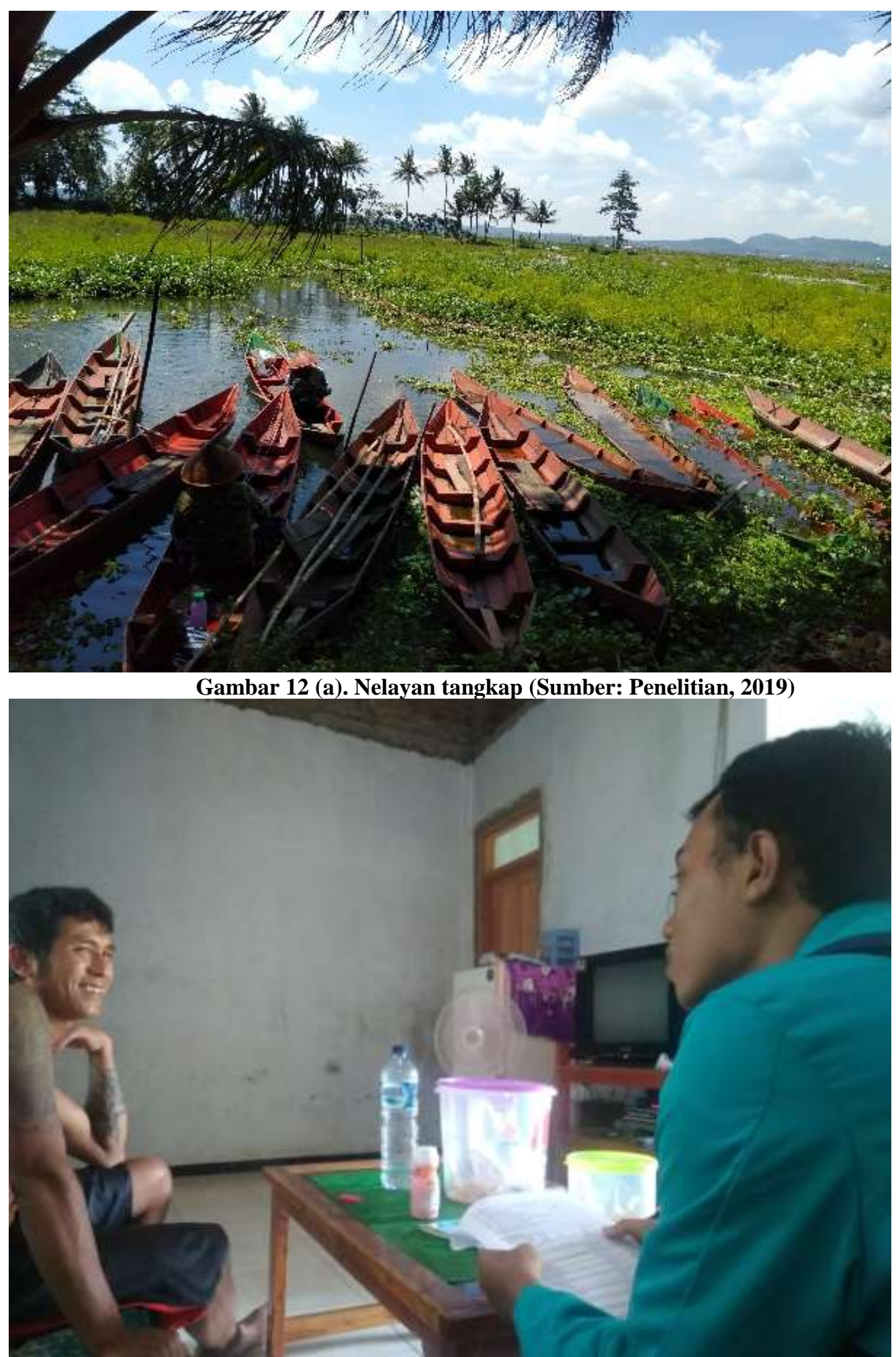

Gambar 12 (b). Wawancara dengan nelayan enceng gondok (Sumber: Penelitian, 2019)

\section{Kesimpulan}

Berdasarkan analisis data yang telah dilakukan, dapat disimpulkan bahwa rata-rata menunjukkan tingkat pendidikan nelayan di Kecamatan Banyubiru tergolong rendah, dengan 
rata-rata pendidikan nelayan tamat SD. Dilihat Rata-rata usia nelayan berusia 51-66 tahun, tingkat usia nelayan paling muda kebanyakan berada di kelompok nelayan Banjangaran. Usia nelayan dengan lama bermatapencaharian sebagai nelayan hampir seimbang. Rata-rata lama bermata pencaharian sebagai nelayan adalah 2 sampai 15 tahun. Hal tersebut karena pekerjaan nelayan bagi mereka sudah menjadi nafas mereka. Meskipun memiliki pekerjaan selain menjadi nelayan, mereka tetap menjadikan nelayan sebagai sumber mata pencaharian utama.

Pendapatan nelayan di Kecamatan Banyubiru tergolong rendah yaitu Rp. 783.000, 00 perbulan sedangkan nelayan dengan pendapatan tertinggi yaitu Rp. 2.349.000, 00 sebanyak 1 orang terdapat pada kelompok nelayan Minarejeki. Rendahnya pendapatan nelayan juga dipengaruhi oleh rendahnya tingkat pendidikan nelayan yang menjadikan mereka susah mendapatkan pekerjaan lain. Kelompok nelayan di Kecamatan Banyubiru didominasi oleh nelayan tangkap. hasil tangkapan nelayan tangkap yang tidak menentu menyebabkan nelayan tangkap beralih ke nelayan keramba maupun enceng gondok. dinamika nelayan tersebut terjadi karena latar belakang ekonomi, yaitu untuk meningkatkan taraf hidup masyarakat nelayan.

\section{Ucapan Terimakasih}

Penulis mengucapkan terimakasih kepada Program Studi Pendidikan Geografi Universitas Muhammadiyah Surakarta yang telah melaksanakan program Praktek Kuliah Lapangan terkait Sosial Ekonomi masyarakat. Penulis juga berterimakasih kepada kelompok nelayan Kecamatan Banyubiru yang telah mengizinkan penulis melakukan penelitian terkait sosial ekonomi mereka. Tidak lupa penulis juga mengucapkan terimakasih kepada orang tua dan dosen pembimbing yang telah memberikan dukungan dengan cara mereka masing-masing.

\section{Daftar Rujukan}

Ardika Sunar Gede I, dkk. 2016. Pengaruh Pendidikan, FEE, Komitmen, dan Tekanan Waktu Pada Kinerja Auditor Kantor Akuntan Publik. ISSN 2302-8556

Bambang Argo Wibowo, dkk. 2012. Analisis Kebijakan Terhadap Aktivitas Penangkapan Ikan Nelayan Karimunjawa Kabupaten Jepara. https://www.researchgate.net/publication/317061199

Harahap Aulia Yupi, dkk. 2013. Analisis Perbedaan Waktu Penangkapan Ikan Alat Tangkap Branjang Terhadap Hasil Tangkapan di Perairan Rawapening Kecamatan Banyubiru Kabupaten Semarang. http://www.ejournal-s1.undip.ac.id/index.php/jfrumt

Hutapea. Y.F Roma, dkk. Peranan Wanita Nelayan (Istri Nelayan) Jaring Insang Dalam Meningkatkan Pendapatan Keluarga di Desa Bejalen, Perairan Rawa Pening Kecamatan Ambarawa Kabupaten Semarang. http://www.ejournals1.undip.ac.id/index.php/jfrumt

Kentasa Abimanyu, dkk. 2016. Analisis Pemanfaatan Sumber Daya Alam Danau Rawa Pening Kabupaten Semarang. http://juornal.unnes.ac.id/sju/index.php/geoimage

Pratama Sadyarta Pratama, dkk. 2012. Analisis Pendapatan Nelayan Tradisional Pancing Ulur di Kecamatan Manggar Kabupaten Belitung Timur. ISSN 2088-3137

Rosni. 2017. Analisis Tingkat Kesejahteraan Masyarakat Nelayan Di Desa Dahari Selebar Kecamatan Talawi Kabupaten Batubara. http://jurnal.unimed.ac.id/2012/index.php/geo

Wasak Martha. 2012. Keadaan Sosial-Ekonomi Masyarakat Nelayan di Desa Kinabuhutan Kecamatan Likupang Barat Kabupaten Minahasa Utara Sulawesi Utara. ISSN 19079672 
Wijayanti Angga, dkk. 2012. Analisis Tingkat Keuntungan Nelayan Gillnet 3/4 Inchi (Jarang Wader) dan Nelayan Gillnet 3 Inchi (Jarang Arang) di Perairan Rawapening Desa Bejalen Kecamatan Ambarawa Kabupaten Semarang. http://www.ejournals1.undip.ac.id/index.php/jfrumt

Yusrizal Firdaus. Tingkat Kesejahteraan Masyarakat Lokal Setelah Diberikan Upaya Pemberdayaan Masyarakat Pada Kawasan Wisata Istana Siak Kabupaten Siak Provinsi Riau. http://repository.unry.ac.id/ 